\title{
BOTHROPS JARARACA (SERPENTES:VIPERIDAE): MATING OBSERVED IN NATURE
}

\author{
BOTHROPS JARARACA (SERPENTES: VIPERIDAE): ACASALAMENTO OBSERVADO NA NATUREZA
}

\author{
Silvia Regina Travaglia Cardoso ${ }^{1 *}$, Bianca dos S. Malagolini ${ }^{2}$ \&Rafael Ferraz ${ }^{2}$
}

${ }^{1}$ Museu Biológico, Instituto Butantan, Avenida Vital Brazil 1500, CEP 05503-900, São Paulo, São Paulo, Brazil.

${ }^{2}$ Dimensão A - Consultoria e Projetos Ambientais, Rua bom Jesus de Pirapora,1001, CEP 13207-605, Jundiaí, São Paulo, Brazil.

Correspondence: silvia.cardoso@butantan.gov.br

Received: 2020-10-13. Accepted: 2021-02-06.

Resumo.- Relatamos um acasalamento de Bothrops jararaca observado na natureza, na Serra do Japi, São Paulo, Brasil.

Palavras chave.- Acasalamento, comportamento reprodutivo, reprodução, Viperidae.

Abstract.- We report a event mating of Bothrops jararaca observed in the wild, in the Serra do Japi, São Paulo, Brazil.

Keywords.- mating, reproduction, reproductive behavior, Viperidae.

Snakes are difficult to study in natural environment because of their secretive habits (Sasa \& Curtis, 2006; Dorcas \& Willson, 2009; Steen, 2010; Clark et al., 2014), thus reports of their reproductive behavior in nature are uncommon. Here we report a mating event of Bothrops jararaca in its natural habitat. In Brazil, B. jararaca is widespread in Atlantic and Araucaria Forest, in primary forests and also disturbed areas with great anthropic influence, including agricultural áreas (Campbell \& Lamar, 2004; Nogueira et al., 2020). Although a common species, mating in nature has not been reported.

The mating event was recorded on the farm "Montanhas do Japi" $\left(23.2490^{\circ} \mathrm{S}, 46.9112^{\circ} \mathrm{W}\right.$ ), Serra do Japi, municipality of Jundiai, São Paulo, Brazil, on 22 March 2018. The snakes were spotted by a group of people during Environmental Education activities on a trail in an area of the Atlantic Forest. The snakes were mating on a sunny morning, after a day of heavy rain, close to 10:00 h. The couple was on a narrow part of the trail, just after a bend, very close to a stream. The snakes were standing still on the left side of the trail, with the bodies partially overlapping and with their tails intertwined. Upon perceiving the approach of people, the snakes showed signs of agitation and the observers promptly moved away. The female started moving and the male, although stationary with the body loosely curled, ended up being dragged by the female. Without interrupting the mating, the snakes climbed the slope towards the forest. In the images (Fig. 1, A-D; lighter female; darker male) it is possible to see part of the male hemipenis and part of the female vaginal pouch entrance everted during the movement.

This partial "eversion" of the female vaginal pouch has already been observed sometimes in captivity during mating of the genus Bothrops (B.neuwiedi, B.fonsecai). When disturbed, the female who is more robust, started moving around and dragging the male. Because the male's hemipenis is still turgid, the movement causes the initial portion of the female vaginal pouch to be exposed. The Fig. 2 shows in detail the partial eversion of the female vaginal pouch, during a mating of $B$. neuwiedi in captivity.

Due to local conditions, it was not possible to accurately assess the difference in length of the snakes, but it was possible to observe that the female was longer and more robust than the male. This observation is in agreement with sexual dimorphism described for adults of this species (Sazima, 1992; TravagliaCardoso, 2001; Furtado et al., 2006). Furthermore, it was not possible to observe in detail the behavioral actions that are part of a mating event, nor the duration of that event. Any insistence on approaching and chasing the snakes would possibly interrupt the mating, which is often long. Our observation in nature (mating in end of March) corroborates the available information about the reproductive cycle of the species, described as seasonal and biennial, with matings occuring in late summer and autumn and births in summer (Sazima, 1992; Almeida-Santos \& Orsi, 2002; Almeida-Santos \& Salomão, 2002). In captivity, late births 

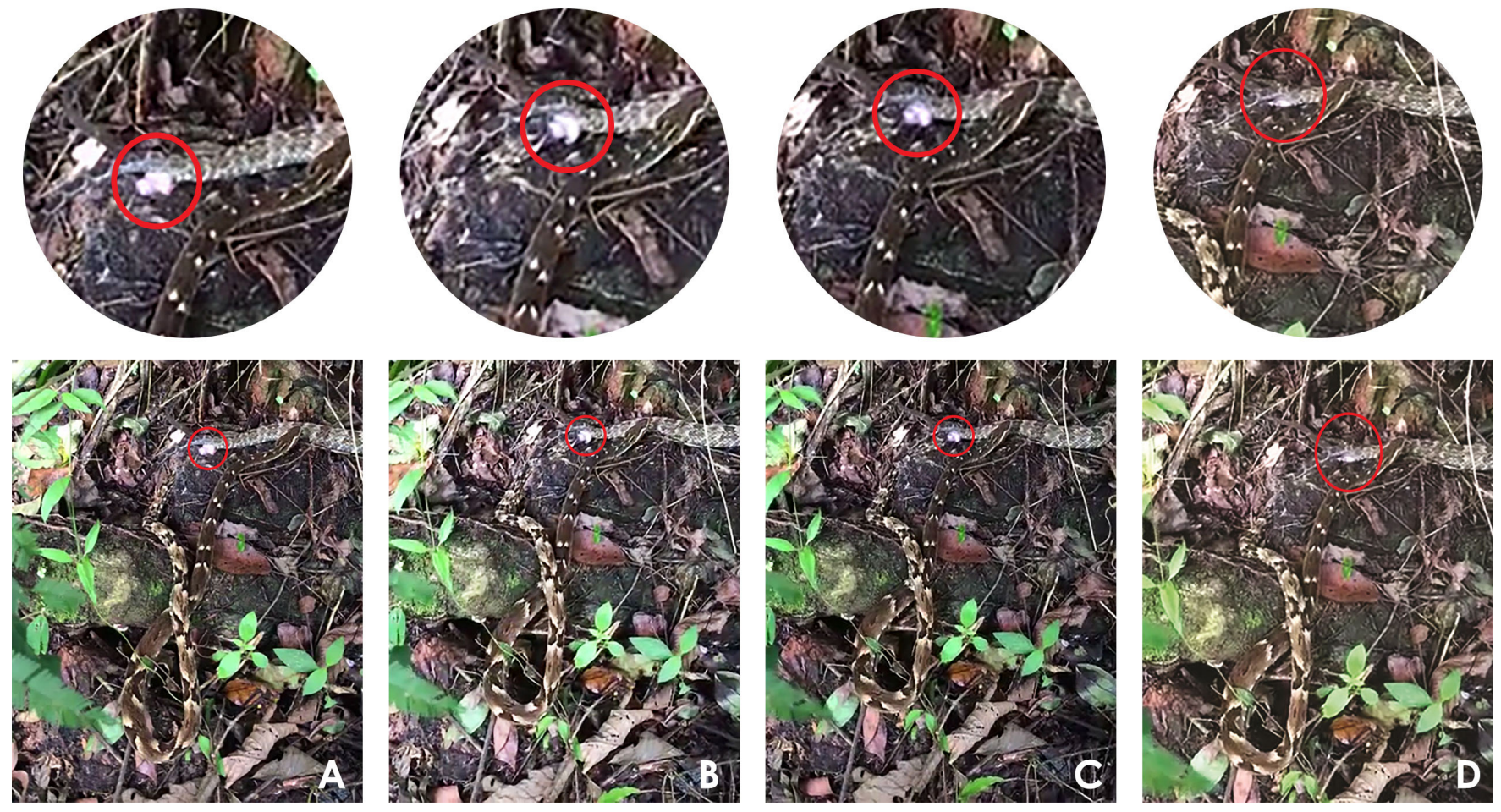

Figura 1 (A-D). - B. jararaca - acasalamento na natureza (mais clara fêmea; mais escuro macho). A fêmea começou a se locomover e o macho foi "arrastado" pela fêmea. Observar parte do hemipênis do macho, e parte da entrada da bolsa vaginal da fêmea evertida (101_LEEV_RLH). Photo: Rafael Ferraz.

Figure 1 (A-D). - B. jararaca - mating in nature (lighter female; darker male). Female started moving and the male ended up being "dragged" by the female. Observe part of the male hemipenis, and part of the female vaginal pouch entrance everted (101_LEEV_RLH). Foto: Rafael Ferraz.

were recorded until April $(\mathrm{n}=2)$ (Travaglia-Cardoso, 2001), and matings $(\mathrm{n}=10$ ) recorded in autumn and winter (June to August) with duration ranging from $6: 20 \mathrm{~h}$ to more of $8: 00 \mathrm{~h}$ (senior author unpublished data).

The images were deposited in the "Photo Bank GERES LEEV", Figure 1: Number 101_LEEV_RLH; Figure 2: Number 102_LEEV_RLH.

\section{CITED LITERATURE}

Almeida-Santos, S. M. \& A. M. Orsi. 2002. Ciclo reprodutivo de Crotalus durissus e Bothrops jararaca (Serpentes, Viperidae): morfologia e função do oviduto. Revista Brasileira de Reprodução Animal 26: 109-112.
Almeida-Santos, S. M. \& M. G. Salomão. 2002. Reproduction in neotropical pitvipers, with emphasis on species of the genus Bothrops. Pp. 445-462. In: G. W. Schuett, M. Höggren, M.E. Douglas \& H.W. Greene (Eds.). Biology of the vipers. Eagle Mountain Publishing, Utah, United States.

Campbell, J. A. \& W.W. Lamar. 2004. The venomous reptiles of the western hemisphere. Cornell University Press, Ithaca, United States.

Clark, R.W., G. W. Schuett, R.A. Repp, M. Amarello, C.F. Smith \& H.W. Herrmann. 2014. Mating Systems, Reproductive Success, and Sexual Selection in Secretive Species: A Case Study of the Western Diamond-Backed Rattlesnake, Crotalus atrox. Plos One 9:1-12. 


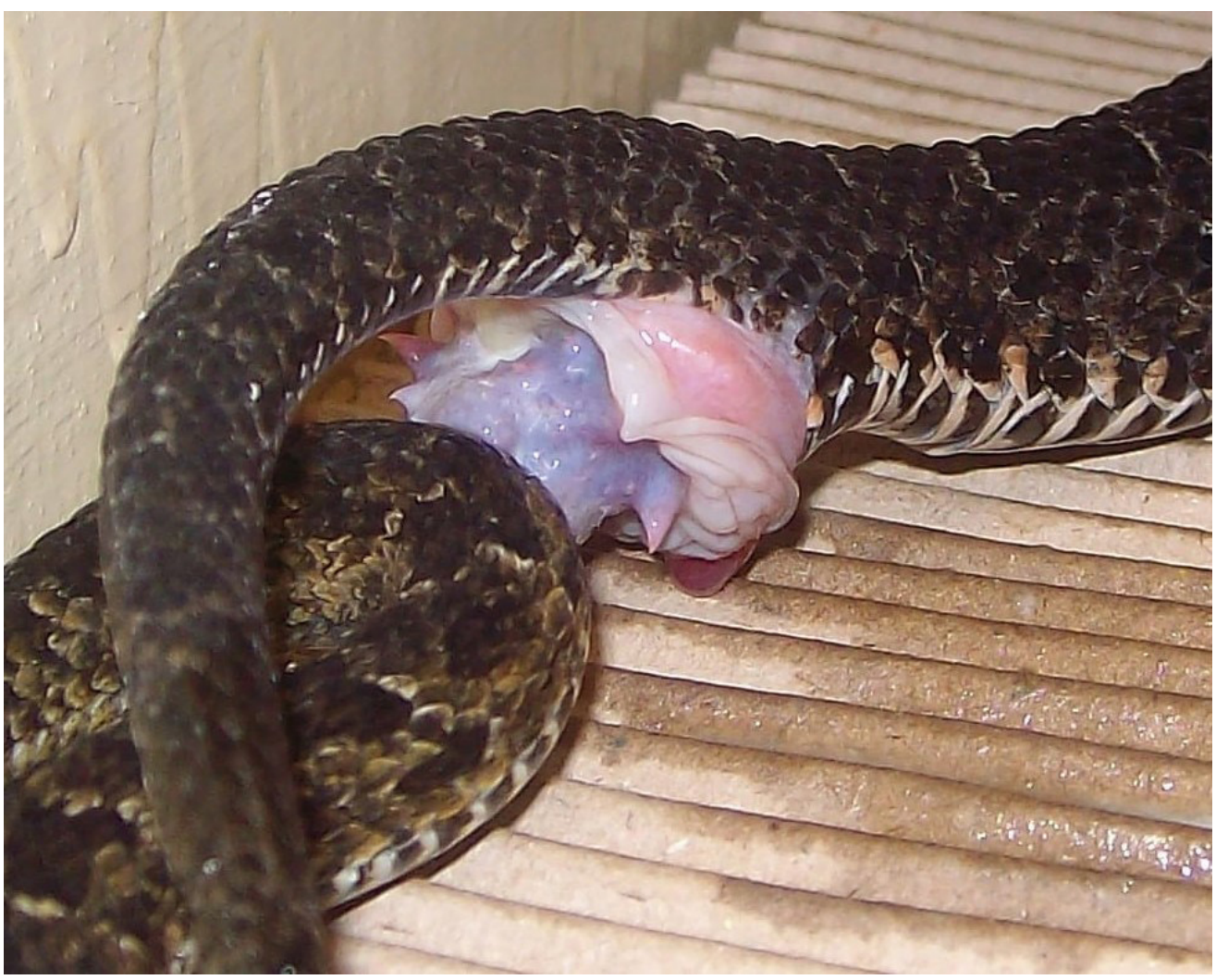

Figura 2. Detalhe de parte do hemipenis e parte exposta da bolsa vaginal da fêmea (B.neuwiedi, durante acasalamento em cativeiro); (102_LEEV_RLH). Foto: Silvia Cardoso. Figure 2. Detail of part of hemipenis and portion of the female vaginal pouch exposed (B. neuwiedi, during mating in captivity); (102_LEEV_RLH). Photo: Silvia Cardoso.

Dorcas, M.E. \& J.D. Willson. 2009. Innovative methods for studies of snake ecology and conservation. Pp. 5-37. In S.J. Mullin \& R.A. Seigel (Eds.). Snakes: Ecology and Conservation. Cornell University Press, Ithaca, United States.

Furtado, M. F.D., S.R. Travaglia-Cardoso \& M. M. T. Rocha. 2006. Sexual dimorphism in venom of Bothrops jararaca (Serpentes: Viperidae). Toxicon 48:401-410.

Nogueira, C.C., A.J.S. Argôlo, V. Arzamendia, J.A. Azevedo, F.E. Barbo, R.S. Bérnils, B.E. Bolochio, M. Borges-Martins, M. BrasilGodinho, H. Braz, M.A. Buononato, D.F. Cisneros-Heredia, G.R. Colli, H.C. Costa, F.L. Franco, A. Giraudo, R.C. Gonzalez, T. Guedes, M.S. Hoogmoed, O.A.V. Marques, G.G. Montingelli, P. Passos, A.L.C. Prudente, G.A. Rivas, P.M. Sanchez, F.C. Serrano, N.J. Silva Jr., C. Strüssmann, J.P.S. Vieira-Alencar, H.
Zaher, R.J. Sawaya, M. Martins. 2020. Atlas of Brazilian Snakes: Verified Point-Locality Maps to Mitigate the Wallacean Shortfall in a Megadiverse Snake Fauna. South American Journal of Herpetology 14: 1-274.

Sasa, M \& S. Curtis. 2006. Field observations of mating behavior in the Neck-banded Snake Scaphiodontophis annulatus (Serpentes, Colubridae). Revista de Biología Tropical 54: 647-650.

Steen, D.A. 2010. Snakes in the grass: secretive natural histories defy both conventional and progressive statistics. Herpetological Conservation and Biology 5: 183-188.

Travaglia-Cardoso, S. R. 2001. Estratégias reprodutivas de Bothrops jararaca (Serpentes, Viperidae). Dissertação de Mestrado. Instituto de Biociências, Universidade de São Paulo. Brasil. 